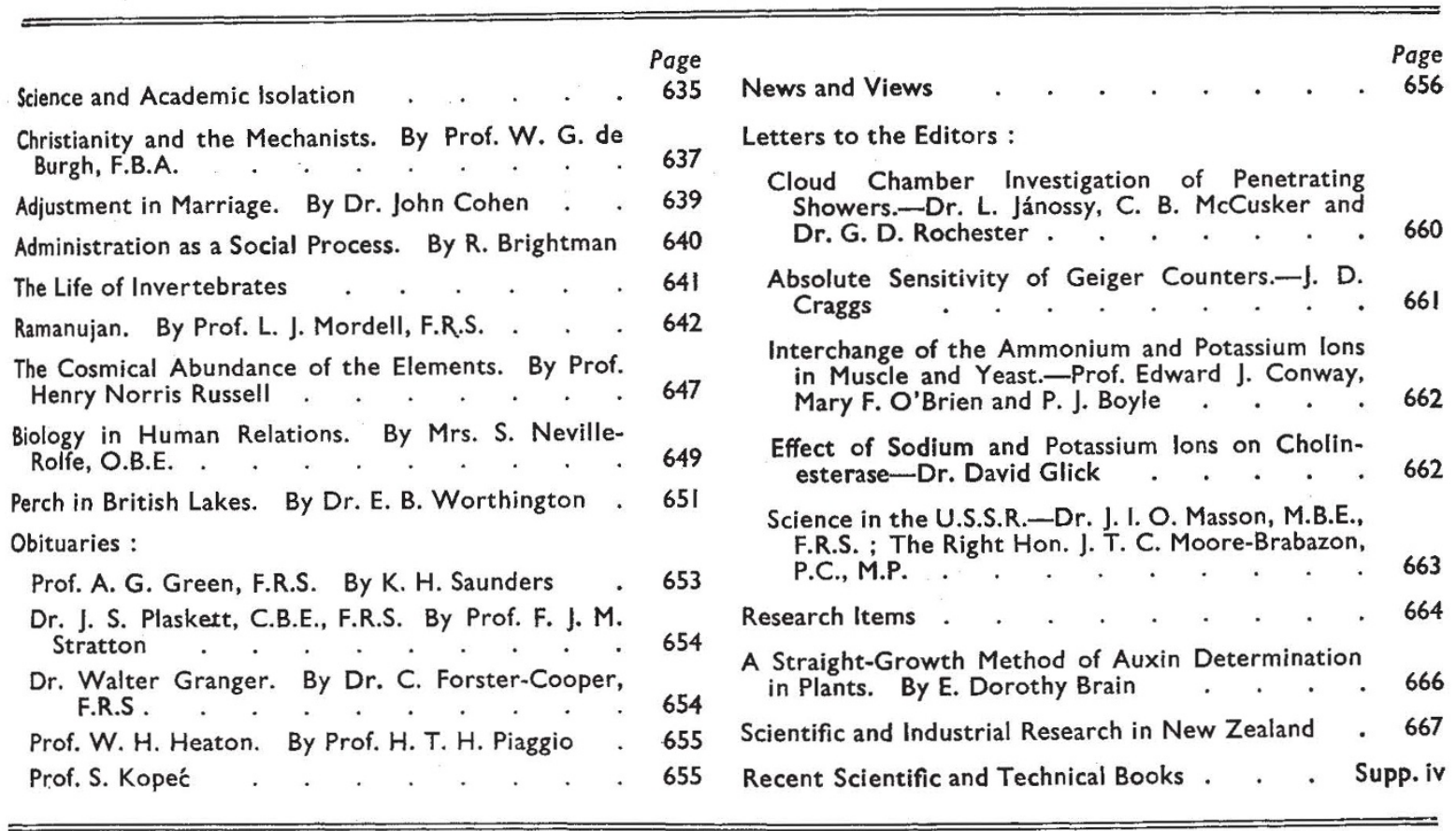

\title{
SCIENCE AND ACADEMIC ISOLATION
}

$\mathrm{T}$ HE recent Conference on Science and World Order organized by the British Association has undoubtedly done much to clarify among men of science a realization of their social responsibilities. More than this, it has initiated, we hope, a deeper understanding on the part of our leaders and statesmen of the vital position science occupies in a modern community. For science is no mere collection of facts and theories, but a living force for progress. Technological advance would be impossible without the background of a scientific culture. The development of the arts of peace owes much to science. The technique of industrial production is an application of scientific knowledge to human needs; large-scale agriculture demands the close collaboration of the farmer and the man of science; public health measures and preventive medicine are often based on the most recent scientific discoveries. It is clear then that increasing the well-being of the ordinary citizen is largely a scientific task. It is equally clear that men of science have not been allowed to direct the application of their results in the social and economic fields to the extent that the importance of their work demands.

In time of war this situation becomes of more serious import, for it is not the development of society which is at stake but its very existence. The exigencies of war raise special problems which can only be solved by the immediate application of scientific knowledge. Yet men of science are employed by Government departments and industrial concerns mainly as advisers with little or no executive authority. Consequently their advice runs the risk of being overlooked or insufficiently implemented. The Civil Servant or factory manager, who in general is not conspicuous for the depth of his scientific knowledge, finds it difficult. to understand that an integrated scientific plan is essential for the efficient operation of the war economy. Piecemeal methods often defeat their own ends. The relevant scientific facts must be considered in totality in determining policy. A better state of affairs would result if men of science were given executive authority in those spheres of the national effort in which their work is directly applicable. Mr. Anthony Eden, in his address of welcome to the foreign representatives attending the British Association Conference, suggested that diplomacy in future must be the servant of science, instead of vice versa. It would be an excellent thing if a beginning along these lines could be made now without waiting for the termination of hostilities. 
But the onus does not rest solely on statesmen and politicians. It rests very largely on men of science themselves. The undoubted fact that the applications of scientific knowledge for the common welfare have often been frustrated or misused has been regarded with complacency or even cynicism by some men of science. Even to-day there is a too prevalent attitude to let things run their appointed course. There still lingers in the minds of some men of science, including several of considerable achievement, a doubt as to the necessity for the planning of science and organization of men of science for social ends. That this doubt is considerable and honestly held is clear. Planning and organization are held to be detrimental to the absolute freedom of the individual man of science to undertake what research he will when he will.

While the maximum freedom in science is necessary, that such absolute freedom of choice is desirable, or even usually obtains, is debatable. It is not sufficiently realized that the type of work that a man of science undertakes in the great majority of instances is conditioned by the fact that he has to earn his living by that work. Except for people with private means and a handful of established university teachers, complete indulgence of the individual's scientific curiosity is impossible. Even in a democratic society, scientific research, taken as a whole, is subject to inevitable restraints and conditions. The problem is not to eliminate them, but to make sure that they are reasonable, socially useful conditions, and that their operation is in the hands of the men of science themselves. This requires democratic organization.

Too often to-day the general guidance of scientific work is in the hands of laymen or persons whose scientific knowledge is incommensurate with the responsibility of their task. We need here to distinguish sharply between conditions of work in university laboratories and research institutions, and those obtaining in industrial and Government laboratories and factories. We need also to appreciate that, particularly in time of war, the overwhelming majority of scientifically trained men and women work under the latter conditions. Sufficient evidence has been accumulated, notably by such bodies as the Association of Scientific Workers, to show that there is room for considerable improvement in many of these places. There can be a great waste of effort among a team of scientific workers if their research is poorly directed and co-ordinated. We are not satisfied that the best use of our scientific brain-power is, in fact, being achieved in this connexion. The frustration the younger scientific worker must inevitably feel when working under inadequate direction was the subject of comment in the leading article of a recent issue of NATURE (November 1). The loss to the nation's effort as a result should also be emphasized.

The long-term view of scientific planning characterized the recent Conference on Science and World Order. It showed that men of science are thinking, in advance, of their part in the planning of the post-war world. Doubts have been expressed as to whether this historic Conference will, in fact, give rise to anything concrete. Surely the correct attitude is to realize that this meeting of men of science was merely an initiation of activity ; but, it should be pointed out, of activity on an international scale. Positive results will only be forthcoming in direct ratio to the amount of help given by the individual man of science. The Division for the Social and International Relations of Science of the British Association has set up several committees to deal with some of the problems arising out of the Conference. These committees should not be left to work in isolation but should be given the fullest assistance and encouragement. It is sincerely to be hoped that they will receive the support required to enable them to make contributions of real and lasting value to society.

The British Association, however, is not a formal representative organization of scientific men, and as such its usefulness, although considerable, is limited in certain respects. There are in Great Britain a number of learned and professional societies and associations. In the past these bodies have been mainly concerned with their own particular interests. Yet in so far as they represent men and women with specialized knowledge, they owe it to their members and to the community to participate in the wider affairs of the nation. At the moment their voice is too often silent. The tradition of academic isolation dies hard.

There are several encouraging features in the present situation. The chief of these is the renewed determination to get things done which is exemplified by many of our leading men of science. It is not generally. realized how deeply this is reflected among the younger rank-and-file scientific workers. Reference to the desirability of including younger brains on many scientific committees was made in the leading article in NATURE already referred to. But in many cases suitable committees do not exist and need to be formed. We are concerned at the present time primarily with the relation of science to winning the war. Regional production committees need not necessarily seek scientific advice, or accept it after having sought it.

In this respect it should be noted that the Scientific Advisory Committee of the Trades Union Congress seems not to function, although it, or a similar 
body, could now express itself directly through T.U.C. members of planning committees. Ways and means should be thought out of bringing scientific advice directly to bodies dealing with industrial production. The application of even elementary scientific research to production problems has resulted in the past in an immense saving both of money and labour. There is no reason for supposing that we have reached saturation point in this respect.

The present war situation calls for considerably increased effort by men of science as much as by the factory worker or farm hand. Pre-war concepts of the pursuit of knowledge for its own sake are not now applicable. Every available scientific brain must be at work on problems connected with the War, and co-ordination of effort must be effected. As Mr. J. G. Crowther said at the British Association Conference, a country which has produced Newton, Clerk Maxwell, Faraday, Rutherford and other towering figures does not lack good men of science, and is not to be defeated for want of them. What we must ensure is that the maximum use is made of them in this critical time for ourselves and our Allies. It is timely, therefore, that the Association of Scientific Workers has announced a conference to be held in January on the general topic of science and the War effort (see p. 657). As this body represents in the main young working men of Science and engineers directly engaged with war and production problems, its voice should receive attention. The general body of scientific workers and technicians should use this opportunity of discussing together their important place in the nation's effort. At the meeting of Soviet men of science held in Moscow on October 12 (NATURE, October 25, p. 490) an appeal was broadcast to scientific workers of the world. Their colleagues in Great Britain have the responsibility of answering their appeal concretely and quickly. Messages of support and encouragement serve a limited purpose only. British men of science and engineers must pool all their knowledge, skill and ingenuity to fulfil their part in the pledge which has been given by Lord Beaverbrook : "We've spoken the word, but you must do the deed."

\section{CHRISTIANITY AND THE MECHANISTS}

Christianity and the Mechanists

By Dr. W. Osborne Greenwood. Pp. 296. (London: Eyre and Spottiswoode (Publishers), Ltd., 1941.) 9s. net.

W HY are writers who approach religious problems from the angle of the sciences so often haphazard in their reasoning, striding forward regardless of obstacles, the moment they quit the strictly scientific beat? They are as reckless as the theologians who dabble in science, and with less excuse; for their scientific training should have taught them to be more careful. The book before us provokes this question. Not that it is lacking in interest or merit, at all events in its negative contentions. The author is a medical man conversant, both within his professional field and outside of it, with the opinions and needs of the public, especially of the younger generation. He knows how their outlook upon the larger problems of life has been prejudiced by uncritical acceptance of the dogmatic tradition of Victorian science, a tradition which still dominates popular thinking, despite the fact that recent developments in physics have gone far to undermine its dogmatism. The majority of the students in our secondary schools and universities still echo the outworn shibboleths and are convinced before their minds are fully fledged that science has scotched religion. It is to such as these, and not to specialist readers, that the author addresses himself.

Dr. Greenwood writes as a believer in Christianity, with engaging sincerity and in a clear and attractive style. He opens with a brief survey (four chapters, comprising the first quarter of the book) of present-day physics, treating with admirable lucidity of the structure of the atom and the problem of entropy, in order to show the grounds that have led many of the leading physicists to postulate a divine mind as the author of the universe. But his main concern is with biology, partly as the field of his own life-work, but chiefly because it is the biologists rather than the physicists who are most solid in their resistance to the hypothesis of theism. $\mathrm{He}$ is out to expose the inadequacy of a mechanistic interpretation of the phenomena of life and mind, save in so far as it is regarded as a methodological assumption. "We must be on our guard against overloading a working hypothesis with more than it will or can carry" (p. 146). He shows clearly that a living organism cannot be fully explained by the analytic method which resolves the whole into an aggregate of its parts (p. 129), and that the form of organization (this holds also of the physical atom and of the electron) is not a material entity or composed of material entities as its constit- 